\title{
The Pollution Effects of Indiscriminate Disposal of Wastewater on Soil in Semi-Urban Area
}

\author{
${ }^{* 1}$ ADEWUMI, JR.; AJIBADE, FO \\ Department of Civil and Environmental Engineering \\ Federal University of Technology, Akure \\ jradewumi@gmail.com; fydelyx87@yahoo.com/foajibade@futa.edu.ng \\ Corresponding author; Tel: +2347062320151,E mail:jradewumi@gmail.com
}

\begin{abstract}
The disposal of wastewater is a problem of great concern throughout the world specifically in developing countries. This study investigates the impact of indiscriminate wastewater disposal on soil in Akindeko and Abiola halls of residence at the Federal University of Technology, Akure Nigeria. Soil samples were taken from the wastewater disposal site at the surface and varying depths of $10 \mathrm{~cm}$ and $20 \mathrm{~cm}$ while the control samples were taken $10 \mathrm{~m}$ away from the polluted soil surface. Physico-chemical and bacteriological properties determined include; colour, odour, soil weight, particle weight, bulk density, porosity, pH, Copper, Manganese, Zinc, Lead, Cadmium, Cobalt, Iron, Sodium, Potassium, Calcium, Magnesium, bacteria, fungi and coliforms. The results showed that all the physicochemical and bacteriological properties of the soils have relatively high concentration indicating pollution compared to the control samples. The $\mathrm{pH}$ ranged from 8.7 to 7.2 while $\mathrm{Ca}$ and $\mathrm{K}$ have a range of $1277 \mathrm{ppm}$ to $773 \mathrm{ppm}$ and $1273 \mathrm{ppm}$ to $754 \mathrm{ppm}$ respectively. The highest concentration of $\mathrm{Zn}$ and $\mathrm{Mn}$ are $19.30 \mathrm{ppm}$ and $11.70 \mathrm{ppm}$ respectively. It is recommended that a sustainable wastewater treatment plant should be provided to treat all wastewater generated from all hall of residence in the university and at the same time the soils in the area require various remediation technologies like bioremediation and phytoremediation by growing certain plants in the area to minimize the rate of contamination and extent of future pollution problems. This will go a long way in preventing environmental pollution in the study area. (C) JASEM
\end{abstract}

http://dx.doi.org/10.4314/jasem/v19i3.10

KEYWORDS: Wastewater, Pollution, Heavy metals, Soil, Semi-urban

Introduction

The menace of environmental pollution has been haunting the human world since early times and is still growing due to excessive growth in developing countries (Ali et al., 2014). Therefore, indiscriminate wastewater disposal deserves a high priority attention in all societies around the world nowadays. Soil pollution resulting from uncontrolled waste discharges into the environment, particularly toxic wastes, is a worldwide phenomenon. Naturally, soil is the richest reservoir of microorganisms and a key component of ecosystems because environmental sustainability depends largely on a sustainable soil ecosystem. Whenever soil is polluted, the ecosystem is altered and agricultural activities are affected (Adedokun and Ataga, 2006; Igwo-Ezikpe et al., 2009). Soil pollution with heavy metals has become a critical environmental concern due to its potential adverse ecological effects. The effects of industrial and municipal wastewater on agricultural soils have been widely documented, mostly with regard to heavy metal concentrations and toxicology (Aydinalp and Marinova, 2003; Chopra et al., 2009; Dominguez-Mariana et al., 2003; Yang, 2002; Rahmani, 2007; Masto et al., 2009; Lokeshwari and Chandrappa, 2006).

The main cause of the problem of Nigerian cities poor environmental conditions according to Sule (2011) can be ascribed to improper disposal and management of wastes and lack of seriousness in the enforcement of rules of waste disposal. Waste management and sanitation is in very deplorable conditions in many third world cities because of weak institutional capacities and lack of financial resources and institutional framework to tackle the menace. Some of these problems include sanitation and environmental issues, disturbed balance of groundwater and contamination of soil and water resources (Ajibade et al., 2014). The problem posed by the pollution of the environment due to man's (anthropogenic) activities is fast becoming a point that should not be overlooked in today's world. There are tendencies that suggest that pollution (air, water 
and land) is fast becoming a modern day evil that has come to live with us. This situation is creating some dangerous effect on human health and well-being. Hence, the basic thrust of this paper is to assess the pollution effects of the indiscriminate disposal of wastewater on soil in Federal University of Technology, Akure, Ondo State, Nigeria.

\section{MATERIALS AND METHOD}

Description of the Study Area: Akure is a city in the South-Western part of Nigeria, and is the urban township capital of Ondo State. It lies on latitude $7^{\circ} 15^{\prime}$ North of the Equator and on longitude $5^{\circ} 15^{\prime}$ east of the Greenwich Meridian (Figure 1). It stands on the altitude of about 370 meters above the sea level. The city has a population of approximately 387,087. The study area is located within Federal University of Technology, Akure (FUTA) as shown in Figure 2. The study was carried out in two locations in FUTA namely, Akindeko and Abiola halls of residence. The wastewater disposal sites are as shown in Plates 1 and 2 .

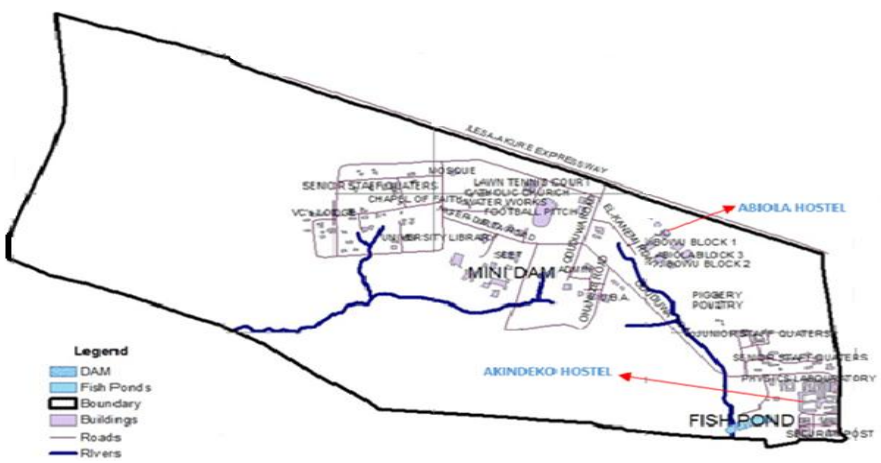

Fig 2: Map of FUTA showing Akindeko and Abiola Hostels

Fig 1: Map of Nigeria Showing Ondo State

(a) Abiola Hall of Residence

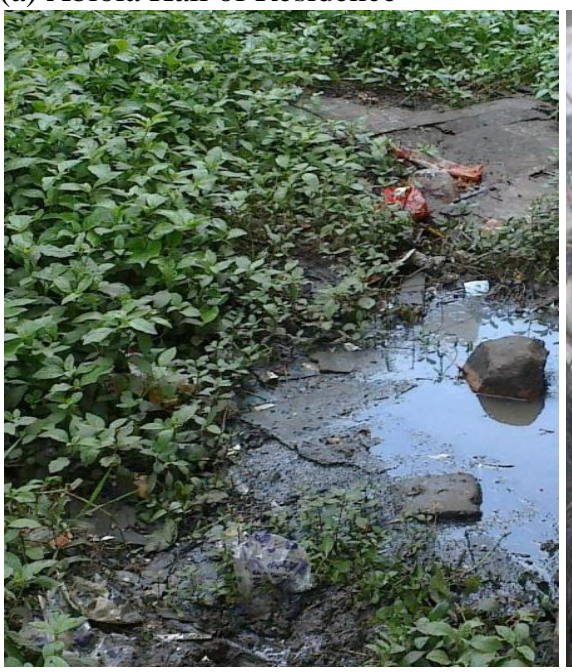

Plate 1: Wastewater Disposal Sites

Soil Sampling and its Laboratory Analysis: The soil samples were collected from Akindeko and Abiola hall of residence in FUTA. The samples were collected from wastewater disposal sites (polluted samples) and at a point far away from the disposal site (control samples). The samples were collected (b) Akindeko Hall of Residence

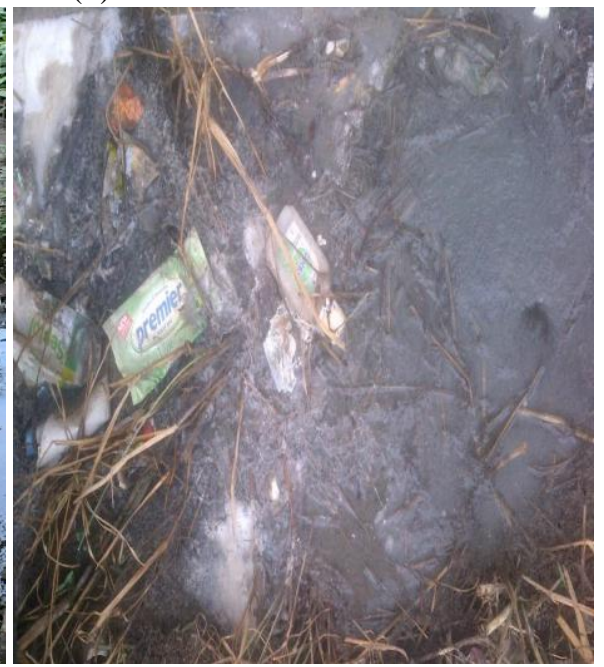


experiment for the physical parameters was carried out at the Geotechnical laboratory of Civil and Environmental Engineering Department, FUTA while the experiment for the biological parameters was carried out at the Biology laboratory, FUTA. The control soil samples were taken at a distance of 10 meters away from the point of pollution. Samples were collected at the surface (top soil) and depths of $10 \mathrm{~cm}$ and $20 \mathrm{~cm}$. The biological parameters determined in the laboratory was, the total colony counts of bacterial, coliform and fungi (microbial biomass).

The experiment for the chemical parameters was carried out at the Postgraduate Research Laboratory, FUTA. The $\mathrm{pH}$ of the samples was determined using the $\mathrm{pH}$ meter, by calibrating the $\mathrm{pH}$ meter using the buffer solutions of known $\mathrm{pH}$ values. The metals such as Copper $(\mathrm{Cu})$, Zinc $(\mathrm{Zn})$, Lead $(\mathrm{Pb})$, Iron $(\mathrm{Fe})$, Sodium (Na), Manganese (Mn), Potassium (K),
Calcium (Ca), Magnesium (Mg), Cadmium (Cd) and Cobalt (Co) values were determined using the Atomic Absorption Spectrophotometer machine.

Statistical analysis: The results obtained were subjected to statistical analysis such as SPSS 20.0. Differences in the mean were separated using new Duncan multiple range test and significance level of $\mathrm{p}<0.05$ used to determine significance.

\section{RESULTS AND DISCUSSION}

The laboratory tests performed on the soil samples are the physical parameters, biological parameters and chemical parameters. The physicochemical and microbial properties of the soil samples from the wastewater disposal sites and control sites in the two halls of residence are presented in Tables $1-4$. The results showed that there were changes in the physicochemical parameters.

Table 1: Summary of the Soil Physical Properties both Control Soil Samples and Polluted Samples for Akindeko and Abiola hostels

\begin{tabular}{lllll}
\hline Parameters & \multicolumn{2}{c}{$\begin{array}{c}\text { Polluted Soil sample/ } \\
\text { Disposal Site }\end{array}$} & $\begin{array}{l}\text { Control Sample } \\
\text { (Upstream Side) }\end{array}$ \\
\cline { 2 - 5 } Colour & Akindeko & Abiola & Akindeko & Abiola \\
Odour & Black & Black & Light Brown & Light Brown \\
Soil weight & Unpleasant & Unpleasant & Normal & Normal \\
Bulk density $\left(\mathrm{g} / \mathrm{cm}^{3}\right)$ & Low weight & Low weight & High weight & High weight \\
Particle Density $\left(\mathrm{g} / \mathrm{cm}^{3}\right)$ & 1.45 & 1.57 & 1.67 & 1.74 \\
Porosity & 1.56 & 1.66 & 2.55 & 2.60 \\
\hline
\end{tabular}

Table 2: Average value of bacteriological parameter at the wastewater

\begin{tabular}{llll}
\multicolumn{4}{c}{ disposal site (Akindeko and Abiola hostel) } \\
\hline \multicolumn{3}{c}{ Microbial Load $\left(\times 1 \mathbf{1 0}^{4}\right)$} \\
\hline Soil Depth & Bacteria & Fungi & Coliforms \\
Control AK & $1.67 \pm 0.02^{\mathrm{a}}$ & $1.10 \pm 0.01^{\mathrm{d}}$ & $1.27 \pm 0.01^{\mathrm{a}}$ \\
Control AB & $1.77 \pm 0.02^{\mathrm{b}}$ & $0.30 \pm 0.01^{\mathrm{a}}$ & $3.13 \pm 0.03^{\mathrm{b}}$ \\
Top AK & $4.90 \pm 0.02^{\mathrm{h}}$ & $2.00 \pm 0.01^{\mathrm{f}}$ & $9.10 \pm 0.05^{\mathrm{f}}$ \\
Top AB & $3.90 \pm 0.01^{\mathrm{e}}$ & $0.53 \pm 0.03^{\mathrm{c}}$ & $3.80 \pm 0.02^{\mathrm{d}}$ \\
$10 \mathrm{~cm} \mathrm{AK}$ & $4.83 \pm 0.01^{\mathrm{g}}$ & $1.90 \pm 0.02^{\mathrm{e}}$ & $9.08 \pm 0.01^{\mathrm{f}}$ \\
$10 \mathrm{~cm} \mathrm{AB}$ & $3.83 \pm 0.02^{\mathrm{d}}$ & $0.57 \pm 0.20^{\mathrm{c}}$ & $3.37 \pm 0.02^{\mathrm{c}}$ \\
$20 \mathrm{~cm} \mathrm{AK}$ & $4.53 \pm 0.01^{\mathrm{f}}$ & $1.86 \pm 0.02^{\mathrm{e}}$ & $8.70 \pm 0.02^{\mathrm{e}}$ \\
$20 \mathrm{~cm} \mathrm{AB}$ & $3.20 \pm 0.02^{\mathrm{c}}$ & $0.37 \pm 0.01^{\mathrm{b}}$ & $3.33 \pm 0.02^{\mathrm{c}}$ \\
\hline
\end{tabular}

Note: AK stands for Akindeko Hall of Residence, AB stands for Abiola Hall of Residence and data are presented as mean \pm standard deviation $(n=3)$. Values with the same superscript letter(s) along the same column are not significantly different $(\mathrm{P}<0.05)$

Table 3: Average value of Mineral composition (heavy metals) at the wastewater disposal site (Akindeko and Abiola hostel)

\begin{tabular}{|c|c|c|c|c|c|c|}
\hline \multirow[b]{2}{*}{ Soil Depth } & \multicolumn{6}{|c|}{ Mineral Composition/Heavy Metals (PPM) } \\
\hline & Copper & Manganese & Zinc & Lead & Cadmium & Cobalt \\
\hline Control AK & $0.40 \pm 0.02^{\mathrm{a}}$ & $11.70 \pm 0.20^{\mathrm{f}}$ & $12.20 \pm 1.0^{\mathrm{a}}$ & $0.10 \pm 0.00^{\mathrm{a}}$ & $0.00 \pm 0.00^{\mathrm{a}}$ & $0.00 \pm 0.00^{\mathrm{a}}$ \\
\hline Control AB & $0.30 \pm 0.00^{\mathrm{a}}$ & $10.90 \pm 0.30 \mathrm{e}$ & $13.00 \pm 0.20^{\mathrm{b}}$ & $0.00 \pm 0.00^{\mathrm{a}}$ & $0.00 \pm 0.00^{\mathrm{a}}$ & $0.00 \pm 0.00^{\mathrm{a}}$ \\
\hline Top AK & $0.50 \pm 0.36^{\mathrm{a}}$ & $8.00 \pm 0.30^{\mathrm{b}}$ & $19.30 \pm 0.10^{\mathrm{f}}$ & $0.80 \pm 0.00^{\mathrm{c}}$ & $1.30 \pm 0.00^{f}$ & $1.60 \pm 0.20^{\mathrm{e}}$ \\
\hline Top AB & $0.40 \pm 0.10^{\mathrm{a}}$ & $7.50 \pm 0.10^{\mathrm{a}}$ & $17.60 \pm 0.30^{\mathrm{e}}$ & $0.80 \pm 0.10^{\mathrm{c}}$ & $1.00 \pm 0.00^{\mathrm{e}}$ & $0.90 \pm 0.00^{\mathrm{cd}}$ \\
\hline $10 \mathrm{~cm} \mathrm{AK}$ & $1.30 \pm 0.20^{\mathrm{b}}$ & $9.90 \pm 0.20^{\mathrm{cd}}$ & $16.50 \pm 0.30^{\mathrm{d}}$ & $1.10 \pm 0.01^{\mathrm{e}}$ & $1.70 \pm 0.10^{\mathrm{g}}$ & $1.10 \pm 0.20^{\mathrm{d}}$ \\
\hline $10 \mathrm{~cm} \mathrm{AB}$ & $1.20 \pm 0.00^{\mathrm{b}}$ & $9.50 \pm 0.20^{\mathrm{c}}$ & $14.20 \pm 0.10^{\mathrm{c}}$ & $0.97 \pm 0.06^{\mathrm{d}}$ & $0.80 \pm 0.10^{\mathrm{d}}$ & $0.80 \pm 0.20^{\mathrm{c}}$ \\
\hline $20 \mathrm{~cm} \mathrm{AK}$ & $1.30 \pm 0.10^{\mathrm{b}}$ & $10.00 \pm 0.30^{\mathrm{d}}$ & $16.40 \pm 0.20^{\mathrm{d}}$ & $0.30 \pm 0.10^{\mathrm{b}}$ & $0.40 \pm 0.10^{\mathrm{c}}$ & $0.30 \pm 0.10^{\mathrm{b}}$ \\
\hline $20 \mathrm{~cm} \mathrm{AB}$ & $1.00 \pm 0.20^{\mathrm{b}}$ & $9.80 \pm 0.10^{\mathrm{d}}$ & $13.90 \pm 0.50^{c}$ & $0.30 \pm 0.10^{\mathrm{b}}$ & $0.20 \pm 0.00^{\mathrm{b}}$ & $0.30 \pm 0.10^{\mathrm{b}}$ \\
\hline
\end{tabular}


Table 4: Average value of Mineral composition at the wastewater disposal site (Akindeko and Abiola hostel)

\begin{tabular}{llllll}
\hline \multicolumn{5}{c}{ Mineral Composition/Metals (PPM) } \\
\hline Soil Depth & Iron & Sodium & Potassium & Calcium & Magnesium \\
Control AK & $208.30 \pm 0.3^{\mathrm{b}}$ & $680.00 \pm 2.00^{\mathrm{b}}$ & $771.70 \pm 0.2^{\mathrm{b}}$ & $859.20 \pm 0.20^{\mathrm{c}}$ & $800.8 \pm 0.10^{\mathrm{c}}$ \\
Control AB & $191.70 \pm 0.20^{\mathrm{a}}$ & $672.80 \pm 0.42^{\mathrm{a}}$ & $754.20 \pm 0.10^{\mathrm{a}}$ & $845.80 \pm 0.10^{\mathrm{b}}$ & $820.8 \pm 1.10^{\mathrm{d}}$ \\
Top AK & $725.00 \pm 2.00^{\mathrm{g}}$ & $904.20 \pm 1.00^{\mathrm{f}}$ & $844.20 \pm 0.90^{\mathrm{d}}$ & $1018.30 \pm 0.2^{\mathrm{e}}$ & $1173.3 \pm 1.00^{\mathrm{h}}$ \\
Top AB & $675.00 \pm 2.00^{\mathrm{e}}$ & $885.80 \pm 1.00^{\mathrm{e}}$ & $836.70 \pm 0.20^{\mathrm{c}}$ & $1002.50 \pm 0.20^{\mathrm{d}}$ & $1083.3 \pm 0.90^{\mathrm{g}}$ \\
$10 \mathrm{~cm} \mathrm{AK}$ & $691.70 \pm 0.1^{\mathrm{f}}$ & $934.20 \pm 0.10^{\mathrm{h}}$ & $1273.30 \pm 0.20^{\mathrm{h}}$ & $1276.70 \pm 1.20^{\mathrm{g}}$ & $989.2 \pm 0.20^{\mathrm{f}}$ \\
$10 \mathrm{~cm} \mathrm{AB}$ & $691.00 \pm 0.00^{\mathrm{f}}$ & $926.70 \pm 0.20^{\mathrm{g}}$ & $1173.30 \pm 0.90^{\mathrm{g}}$ & $1250.80 \pm 0.10^{\mathrm{f}}$ & $964.2 \pm 0.90^{\mathrm{e}}$ \\
$20 \mathrm{~cm} \mathrm{AK}$ & $584.2 \pm 1.0^{\mathrm{d}}$ & $804.20 \pm 1.10^{\mathrm{d}}$ & $1005.80 \pm 0.90^{\mathrm{f}}$ & $773.30 \pm 1.10^{\mathrm{a}}$ & $757.5 \pm 1.00^{\mathrm{b}}$ \\
$20 \mathrm{~cm} \mathrm{AB}$ & $525.0 \pm 2.00^{\mathrm{c}}$ & $787.50 \pm 0.20^{\mathrm{c}}$ & $994.20 \pm 0.10^{\mathrm{e}}$ & $774.20 \pm 1.10^{\mathrm{a}}$ & $740.8 \pm 0.90^{\mathrm{a}}$ \\
\hline
\end{tabular}

From Table 1, the colour of the soil samples from the wastewater disposal sites are black which indicate a high organic content while the control are light brown in colour because of the combination of iron oxides and organic content. The odour is unpleasant and normal for the polluted soil samples and control soil samples respectively from the two halls of residence. The soil weight is low and high for the polluted soil samples and control soil samples respectively from the two halls of residence. Soils with a bulk density higher than $1.6 \mathrm{~g} / \mathrm{cm}^{3}$ tend to restrict root growth as obtained from the control samples of the two halls of residence. Porosity of soils gives a good indication of the suitability for root growth and soil permeability and are vitally important for soil-plant-atmosphere system (Cresswell and Hamilton, 2002; McKenzie et al., 2004). It is generally desirable to have soil with a low bulk density $\left(<1.5 \mathrm{~g} / \mathrm{cm}^{3}\right)$ for optimum movement of air and water through the soil (Hunt and Gilkes, 1992) as obtained in soil samples at the wastewater disposal site in Akindeko hall of residence. Generally, particle density of normal soils is 2.65 $\mathrm{g} / \mathrm{cm}^{3}$. The particle density of soil is higher if large amount of heavy minerals such as magnetite, limonite and hematite are present in the soil. Increase in organic matter of the soil decreases the particle density as depicted by the polluted soil samples from the two halls of residence. Mean porosity were 0.07 , $0.05,0.35$ and 0.33 for the polluted soil samples and control soil samples respectively from the two halls of residence (Table 1).

The $\mathrm{pH}$ of the soil increased significantly from 6.9 (control) to 8.6 (for the top soil samples obtained from Akindeko) and 7.2 (control) to 8.21 (for the top soil sample obtained from Abiola). This shows that soil with a $\mathrm{pH}$ value greater than 8.5 is less suitable and soils with a $\mathrm{pH}$ value range of 6.5 to 8.5 are most suitable (Figure 1). Therefore, soils obtained at the top of the wastewater disposal sites indicates pollution and will require special management techniques. Most of the soil samples showed an alkaline $\mathrm{pH}$ during the study period, possibly attributable to the presence of detergents and soapy water and as a result of the sorption of metals in the soil (Lee and Sauders, 2003). This is acceptable since wastewater with low $\mathrm{pH}$ is difficult to treat by biological means and may also alter the concentration in natural waters (Metcalf and Eddy, 2003).

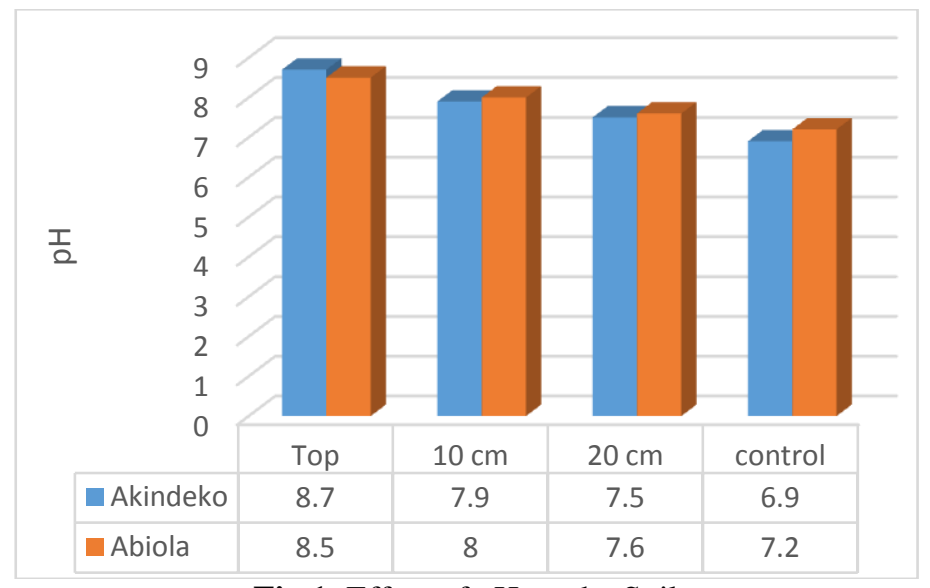

Fig 1: Effect of $\mathrm{pH}$ on the Soil 
Mineral Composition of the Soil Samples: There are no significant difference in the level of copper pollution in the control and the top soil of the two halls of residence (Akindeko and Abiola). Also, the level of copper pollution at the depths of $10 \mathrm{~cm}$ and $20 \mathrm{~cm}$ in the two halls of residence are not significantly different.

The control samples of the two halls of residence have the highest level of manganese pollution. Samples at the depths of $10 \mathrm{~cm}$ and $20 \mathrm{~cm}$ from the two halls of residence are not significantly different in the level of pollution (Figure 2). Samples obtained from the top soil of Abiola hall of residence have the lowest level of Manganese content. The level of pollution in the soil sample obtained at the depth of $10 \mathrm{~cm}$ in Akindeko hall of residence has no significant difference from the depth of $10 \mathrm{~cm}$ soil sample obtained from Abiola hall of residence and the depth of $20 \mathrm{~cm}$ soil samples obtained from the two halls of residence.

The level of zinc pollution from soil samples obtained at the depths of $10 \mathrm{~cm}$ and $20 \mathrm{~cm}$ in Akindeko hall of residence are not significantly different while the level of pollution at the depths of $10 \mathrm{~cm}$ and $20 \mathrm{~cm}$ in Abiola hall of residence are not also significantly different $(\mathrm{P}<0.05)$. The top soil sample obtained from Akindeko hall of residence has the highest level of zinc content followed by the top soil sample obtained from Abiola hall of residence (Figure 2). The zinc content is very low from the control samples obtained from the two halls of residence.

The level of $\mathrm{Pb}$ pollution in the control soil samples (has the lowest content of $\mathrm{Pb}$ ) and top soil samples obtained from the two halls of residence are significantly different and not significantly different respectively $(\mathrm{P}<0.05)$. The soil samples obtained from the two halls of residence at the top soil and depth of $10 \mathrm{~cm}$ has the highest level of $\mathrm{Pb}$ pollutant (Figure 2).

The highest level of Cadmium content was found in the soil samples obtained from the depth of $10 \mathrm{~cm}$ in Akindeko hall of residence followed by the top soil sample analyzed from the same location. The level of $\mathrm{Cd}$ pollution in the control soil samples has the lowest content of $\mathrm{Cd}$ and are not significantly different.

The control soil samples analyzed from the two halls of residence has the lowest level of cobalt pollution while the top soil samples from Akindeko hall of residence has the highest content of cobalt. There is no significant difference from the soil samples obtained at the depth of $20 \mathrm{~cm}$ in the two halls of residence $(\mathrm{P}<0.05)$.

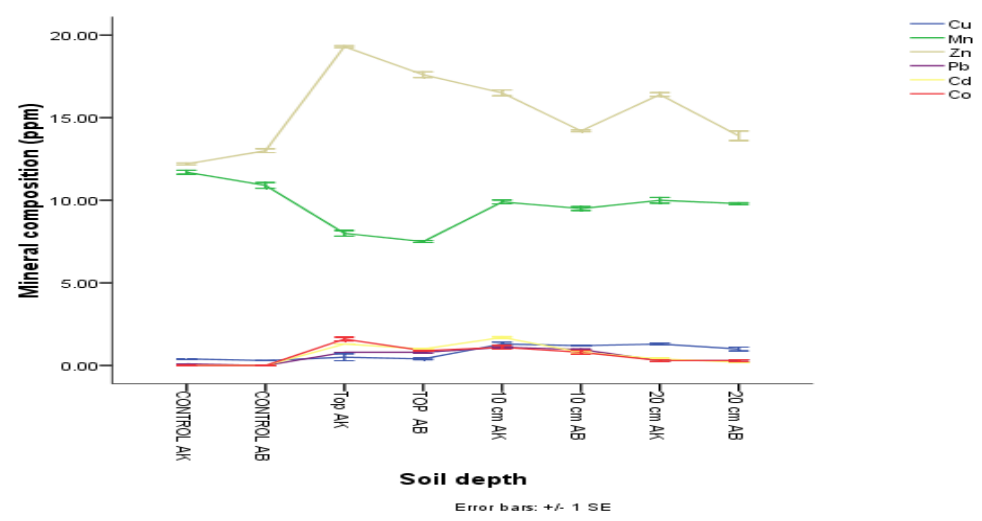

Fig 2: Effect of Mineral Composition (Heavy Metals) on the Soil

The top soil samples obtained at Akindeko hall of residence has the highest level of iron while the control sample obtained from Abiola has the lowest content (Figure 3). There is no significant difference from the soil samples obtained at the depth of $10 \mathrm{~cm}$ in the two halls of residence however there is significant difference from the soil samples obtained from the top soil samples in the two halls of residence $(\mathrm{P}<0.05)$.
The level of contamination of sodium and potassium at each of the soil depth are significantly different. The soil samples obtained at depth of $10 \mathrm{~cm}$ has the highest level of contamination whereas the control soil samples obtained at Abiola hall of residence has the lowest level of contamination.

The soil samples obtained at depth of $10 \mathrm{~cm}$ in Akindeko hall of residence has the highest level of calcium pollution. The soil samples obtained at the 
depth of $20 \mathrm{~cm}$ from the two halls of residence has the least level of contamination and are not significantly different.

The levels of magnesium pollution at all the soil depths are significantly different. The top soil samples obtained from Akindeko hall of residence has the highest level of pollution while the soil samples obtained from Abiola hall of residence at depth of $20 \mathrm{~cm}$ has the lowest level of Mg pollutant.

Heavy metals are known to accumulate in soils and have persistence time through interaction with soil component and consequently enter food chain through plants or animals. The high concentration of some of the metals is an indication of an occurrence of the exchangeable species of the metals in soil from wastewater disposal sites and has both natural and anthropogenic implications. Furthermore, the relatively low average content of $\mathrm{Pb}$ obtained from soils of Akindeko and Abiola Halls of residence in this study (Figure 2 and Table 3), much as it presents insignificant exposure risks; do not rule out the possibility of increase in $\mathrm{Pb}$ levels with time. Other previous findings by Madrid et al., (2002) had reported that the extent of heavy metal pollution varied with age, particularly for $\mathrm{Cu}$ and $\mathrm{Pb}$ (Chen et al., 2005).

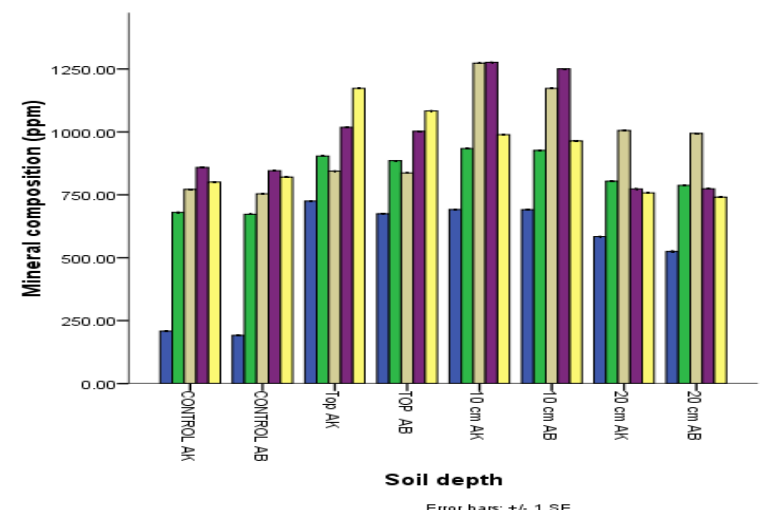

Fig 3: Effect of Mineral Composition on the Soil

Microbial Load Pollution: The control soil samples for the Akindeko hall of residence has the least bacterial and coliforms infection while the depths of $10 \mathrm{~cm}$ and $20 \mathrm{~cm}$ soil samples are highly polluted with microbial load (Bacteria, Fungi and Coliforms). The control soil samples obtained from Abiola hall of residence has the minimum infection of fungi. Statistically, there are no significant differences between soil samples analyzed for fungi from Akindeko hall of residence at depths $10 \mathrm{~cm}$ and 20 $\mathrm{cm}$ and from Abiola hall of residence at the top and at depth of $10 \mathrm{~cm}$. The soil samples analyzed for coliform from Abiola hall of residence at depths 10 $\mathrm{cm}$ and $20 \mathrm{~cm}$.
The control samples from the Akindeko and Abiola hall of residence were mildly polluted by the microbial load (Bacteria, Fungi and Coliforms). The samples obtained at the top and at depths $10 \mathrm{~cm}$ and $20 \mathrm{~cm}$ wastewater disposal site at Akindeko hall of residence were highly polluted compared to that of Abiola hall of residence (Figure 4). This can be attributed to the fact that Akindeko hall of residence has high population of students contributing to the wastewater flow. From the statistical analysis (Table 2), there are significant differences between the control samples and soil obtained from the top, depth of $10 \mathrm{~cm}$ and $20 \mathrm{~cm}$ for Akindeko and Abiola halls of residence. 


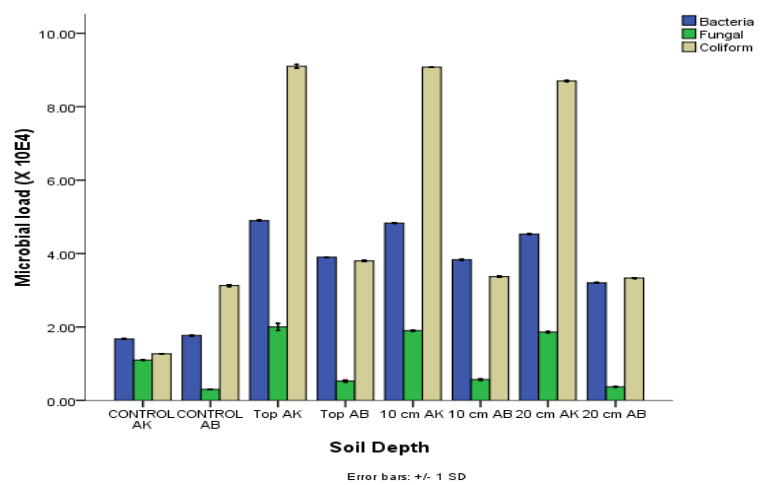

Fig 4: Effect of Microbial Load on the Soil

Conclusion: The study revealed that the indiscriminate disposal of wastewater into the environment contaminate the soil ecosystem. This is evident by higher metal concentration and microbial load above the range of values obtained from the control sites of the two halls of residence investigated. It can also be concluded that the level of pollution in soil samples analyzed from Akindeko hall of residence was higher compared to the soil samples from Abiola hall of residence due to age of the hostel, high population of resident students, improper disposal of waste material and faeces, poor hygiene of the students living in Akindeko hall of residence. Among the analyzed elements, Calcium and Potassium had the highest concentration which ranged between 773 to $1277 \mathrm{ppm}$ and 754 to 1273 ppm respectively in the wastewater disposal sites. The concentration of some elements and heavy metals $\mathrm{Fe}, \mathrm{Zn}, \mathrm{Ca}, \mathrm{Na}, \mathrm{K}$ and $\mathrm{Mg}$ in soils have been found to be higher than their normal concentration in soils. Therefore, it can be deduced that continuous uncontrolled disposal of wastewater on land affect soil physicochemical properties and release of concentrated leachate to the environment will further become potential source of entry into the food chain. Currently, there is no any pollution control method being practiced at the specific disposal sites. Ultimately, optimal management lies with the establishment of a sustainable wastewater treatment plant to treat wastewater before disposal. By proper disposing of wastewater it will lessen the impact of heavy metals on soils of the study areas, hence, it will promote the economical use of the land. The soils in the area require various remediation technologies like bioremediation and phytoremediation by growing certain plants in the area to minimize the rate of contamination and extent of future pollution problems.

\section{REFERENCES}

Adedokun, O.M. and Ataga A.E., (2006). Effects of Crude Oil and Oil Products on Growth of Some
Edible Mushrooms. Journal of Applied Science and Environmental Management. 10(2): 91 - 93.

Ajibade, F. O., Adewumi, J. R. and A. M. Oguntuase (2014). Sustainable Approach to Wastewater Management in the Federal University of Technology, Akure, Nigeria. Nigerian Journal of Technological Research, 9(2): 27-36.

Ali, S.M., Pervaiz, A., Afzal, B., Hamid, N., and Yasmin, A. (2014). Open dumping of municipal solid waste and its hazardous impacts on soil and vegetation diversity at waste dumping sites of Islamabad city. Journal of King Saud University - Science 26: 59 - 65.

Aydinalp, C. and Marinova, S. (2003). Distribution and forms of heavy metals in some agricultural soils, Polish Journal of Environmental Studies, 12 (5): 629 - 633.

Chen, T.B., Y.M. Zheng, M. Lei, Z.G. Hunag, H.T. Wu,H. Chen, K.K. Fan, K. Yu, X. Wu and Q.Z. Tian. (2005). Assessment of heavy metal pollution in surface soils of urban parks in Beijing, China. Chemosphere 60: 542-551.

Chopra, A. K., Chakresh P., and Prasad, G., (2009). Scenario of heavy metal contamination in agricultural soil and its management. Journal of Applied and Natural Science 1(1): 99 - 108.

Cresswell, H.P. and Hamilton, G. J. (2002). Particle Size Analysis. In: Soil Physical Measurement and Interpretation for Land Evaluation. (Eds. N.J. McKenzie, H.P. Cresswell and K.J. Coughlan) CSIRO Publishing: Collingwood, Victoria. pp 224-239.

Domłnguez-Mariana, E., Carrillo-Chvez, A. and Ortega A. (2004). Wastewater reuse in valsequillo agricultural area, Mexico: 
environmental impact on groundwater. Journal of Water, Air and Soil Pollution 155: 251-267.

Hunt, N. and Gilkes, R. (1992) Farm Monitoring Handbook. The University of Western Australia: Nedlands, Western Australia.

Igwo-Ezikpe, M.N., Gbenle, O.G., Ilori, M.O., Okpuzor J., and Osuntoki, A.A. (2009). Evaluation of Alcaligenes faecalis Degradation of Chrysene and Diesel Oil with Concomitant Production of Biosurfactant. Research Journal of Environmental Toxicology 3(4): 159-169.

Lee, M.K. and Sauders, J.A. (2003). Effect of pH on metal precipitation and sorption: Field bioremediation and geochemical modeling approaches. Vadose Zone Journal, 2:177-185

Lokeshwari, H. and Chandrappa, G.T. (2006). Impact of heavy metal contamination of Bellandur Lake on soil and cultivated vegetation. Current Science, 91 (5): 622 - 627.

Madrid, L., Diaz-Barrientos, E. and Madrid, F. (2002). Distribution of heavy metal contents of urban soils inparks of Seville. Chemosphere 49: 1301-1308.

Masto, R.E., Chhonkar, P.K., Singh, D. and Patra, A.K. (2009). Changes in soil quality under long term sewage irrigation in a sub-tropical environment. Environmental Geology 56(6): 1237-1243
McKenzie, N.J., Jacquier, D.J., Isbell, R.F. and Brown, K. L. (2004). Australian Soils and Landscapes; An Illustrated Compendium.CSIRO Publishing: Collingwood, Victoria.

Metcalf and Eddy, Inc., (2003). Wastewater Engineering Treatment and Reuse, Fourth Edition, McGraw Hill, New York.

Mishra, A. and Tirpathi, B.D. (2008). Concurrent removal and accumulation of heavy metals by the three aquatic macrophyte. Journal of Hazardous Materials, 164:1059-1063.

Rahmani, H. R. (2007). Use of industrial and municipal effluent water in Esfahan provinceIran. Scientific Research and Essay 2(3):84 - 88.

Sule, A. B. (2011). Management of Environments in Africa: A Handbook and References, Lagos: Greenwood Publishing Group Inc.

Yang H X, (2002). Effects of irrigation with wastewater on the crops in Datong, Shanxi China Journal of Agro-Environment and Development, 4: 18-19. 